\title{
Pesantren dan Perguruan Tinggi
}

\author{
Dr. KH. Safradji, M.Pd.I \\ STIT Aqidah Usymuni Sumenep
}

\begin{abstract}
Pesantren as an Islamic educational institution with a boarding system is an aducation that with has astrategic position in tradinal society, especially among students. This position anables pesantren to become a vehicle for effective empowerment for the community while remaining grounded in the cultural values that underlie it.

Islamic boarding schools appear to be an institution that has various facilities to build the potential of students, not necessarily terms of moral, intellectual and spiritual values, but also physical and material attributs.

The article talk camly about the pesantren and Islamic higher educations. That Islamic boarding schools and Islamic higher education can be synchronize as an innovative effort to prepare the human resources needed in this day.
\end{abstract}

\section{Keywords : Pesantren and Islamic higher Education}

\section{Pendahuluan}

Sebagai unit lembaga pendidikan dan sekaligus lembaga dakwah, pesantren ${ }^{1}$ pertama kali dirintis oleh Shaikh Maulana Malik Ibrahim pada $1399 \mathrm{M}$ yang berfokus pada penyebaran agama Islam di Jawa. ${ }^{2}$ Selanjutnya, tokoh yangberhasil mendirikan dan mengembangkanpesantrenadalah Raden Rahmat (Sunan Ampel). Pesantren pertama didirikan di Kembangkuning, yang waktu itu hanya dihuni oleh tiga orang santri, yaitu Wiryo Suroyo, Abu Hurairah, dan Kyai Bangkuning.Pesantren tersebut kemudian dipindahkan ke kawasan Ampel di seputar Delta Surabaya karena ini pulalah Raden Rahmat akhirnya dikenal dengan

\footnotetext{
1 Lebih lanjut lihat, Pola Pembelajaran di Pesantren (Jakarta: Proyek Peningkatan Pondok pesantren Departemen Agama RI, 2001), 4. Banyak penulis sejarah pesantren bahwa institusi ini merupakan hasil adopsi dari model perguruan yang diselenggarakan orang-orang Hindu dan Budha yang menggunakan sistem biara dan asrama sebagai tempat para pendeta dan bhiksu melakukan kegiatan pembelajaran kepada para pengikutnya. Bentuk pendidikan seperti ini kemudian menjadi contoh model bagi para wali dalam melakukan kegiatan penyiaran dan pengajaran Islam kepada masyarakat luas, dengan mengambil bentuk sistem biara dan asrama dengan merubah isinya dengan pengajaran agama Islam yang kemudian dikenal dengan sebutan pesantren.

2 Ronad Alan Luiekens Bull, A Peacefull Jihad: Javanese Education and Religion Identity Construvtion (Michigan: Arizona State University, 1977), 60.
} 
sebutan Sunan Ampel. Selanjutnya, putra dan santri dari Sunan Ampel mulai mendirikan beberapa pesantren baru, seperti pesantren Giri oleh Sunan Giri, Pesantren Demak oleh Raden Patah, dan Pesantren Tuban oleh Sunan Bonang. ${ }^{1}$ Fungsi pesantren pada awalnya hanyalah sebagai media Islamisasi yang memadukan tiga unsur, yaitu ibadah untuk menanamkan iman, tabligh untuk menyebarkan Islam, dan ilmu serta amal untuk mewujudkan kegiatan sehari-hari dalam kehidupan bermasyarakat. ${ }^{2}$

Sedangkan faktor-faktor yang mempengaruhi pelembagaan pesantren adalah pertama,pengaruhtarekat terhadap pelembagaan pesantren karena salah satu elemen dari tradisi pesantren adalah tarekat. Melembagakan sistem pendidikan pesantren tidak dapat dipisahkan dari kegiatan tarekat. Menurut Dhofier, tarekat mempunyai arti penting bagi terbentuknya pesantren. Tradisi pesantren sejak bentuknya yang paling tua merupakan suatu kombinasi antara madrasah dan pusat kegiatan-kegiatan tarekat. Pola kombinasi madrasah dan tarekat inilah yang tumbuh di jawa dan tidak mempertentangkan antara aspek syari'at dan aspek tarekat. $^{3}$

Martin Van Bruinessen telah menelusurijejak terekat pada awal penyebaran Islam. Dari beberapa kronika Jawa ia menemukan nama-nama seperti Shaikh Zainal Kubro, Shaikh Jumadil Kabit, dan Shaikh Jumadil Makbur. Dari namanama ini Martin Van Bruinessen mencoba menelusuri hubungan Tarekat Kubrawiyyah dengan Jawa pada masa awal penyebaran Islam. Namun Jumadil Kubra kemungkinan penyimpangan dari nama Najmuddin al-Kubra (w. $1221 \mathrm{M}$ ), pendiri Tarekat Kubrawiyyah. Namun, nama-nama tersebut tidak satupun yang merujuk pada Najmuddin al-Kubra sehingga ia menyimpulkan bahwa tidak ada pengaruh Tarekat Kubrawiyyah di Jawa. Memang arketip Jumadil Kubra dijunjung tinggi di Jawa pada masa awal penyebaran Islam, tetapi karena tidak

\footnotetext{
${ }^{1}$ Wahjoetomo, Perguruan Tinggi Pesantren (Jakarta: Gema Insani Press, 1997),70.

${ }^{2}$ Ibid, 70 .

${ }^{3}$ Zamakhsyari Dhafier, Tradisi Pesantren, 34.
} 
adanya ciri khas yang dapat dirunut sebagai Najmuddin al-Kubra menunjukkan bahwa pengaruhnya tidak mendalam. ${ }^{4}$

Kedua,pengaruh haji terhadap pelembagaan pesantren. Sebab bagi orang-orang Jawa termasuk di Asia tenggara, haji menjadi bagian penting dari kehidupan keagamaan. Sejak masa yang sangat awal, sudah ada orang-orang Jawa yang pergi ke Makkah untuk menjalankan ibadah haji padahal perjalanan ke Tanah Suci harus ditempuh dengan berat dan penuh resiko. Jaraknya sangat jauh dan perjalanan yang harus ditempuh memakan waktu lama dan berbahaya. Para calon jamaah haji harus turut dalam kapal-kapal perdagangan dengan berdesak-desakan; diterjang gelombang; dan menghadapi perompak-perompak di perjalanan. ${ }^{5}$

\section{Tipologi Kepemimpinan Kyai}

Terkait periodisasi kepemimpinan Islam di Indonesia,Jalaluddin Rakhmat membaginya menjadi tiga fase, yaitu fase ulama, fase organisator, dan fase pemuka pendapat (opinion leader), ${ }^{6}$ yang ketiganya memiliki ciri khasnya masing-masing.

Fase pertama (fase ulama) dikatakan bahwa seorang dapat menjadi pemimpin Islam karena ia memiliki pengetahuan agama yang mendalam sehingga dijadikan rujukan umat. Di fase ini seorang pemimpin melewati masa-masa mudanya di pesantren sebagai seorang santri, kemudian menghabiskan sisa hidupnya sebagai seorang kyai yang membina pesantren. Artinya, pesantrendituntut agar menghasilkan out putberupa "agen-agen" kyai untuk disebarkan ke seluruh penjuru Nusantara sehingga, lewat para santrinya, kyai bisa melebarkan pengaruhnya secara nasional.Fase kedua (fase organisator) lebih merupakan reaksi terhadap kebijakan politik pemerintahan kolonial Belanda.Dalam hal ini, umat Islam mendirikan organisasi, seperti Syarikat Islam, Muhammadiyah, NU, Persis, Jami'Khair, dan lain-lain.Yang disebut sebagai

\footnotetext{
${ }^{4}$ Martin Van Bruinessen, Kitab Kuning, Pesantren dan Tarekat (Yogyakarta: Gading Publishing, 2012), 225.

${ }^{5}$ Ibid, 49.

6 Jalaluddin Rakhmat, "Mempersoalkan Asal Usul Pemimpin Islam", dalam Maksum (ed).,Mencari Pemimpin Umat: Polemik Tentang Kepemimpinan Islam di Tengah Pluralitas Masyarakat (Bandung: Mizan, 1999), 28-34.
} 
pemimpin Islam di fase ini adalah pemimpin organisasi Islam sendiri. Tentunya, karir sang pemimpin di sini tidak dimulai dari rahim pesantren, tetapi dari organisasi. Fase ketiga, yakni fase pemuka pendapat (opinion leader). Artinya, apa yang disebut sebagai pemimpin Islam adalah mereka yang pandai melontarkan gagasan-gagasan inovatif melalui media cetak, media elektronik, diskusi, seminar, dan lain sebagainya. Dari fase ketiga ini kemudian banyak bermunculan dua jenis pemimpin, yaitu mubaligh dan cendikiawan. ${ }^{7}$

Kembali pada persoalan mengenai kepemimpinan kyai di pesantren. Penting untuk ditegaskan di sini bahwa seorang kyai pada umumnya identik dengan kepemimpinan kharismatik, walaupun belakangan ini mulai berkembang apa yang disebut rekonseptualisasi dan refungsionalisasi pada struktur pesantren. Berkat kharismanya, menurut pandangan Sartono Kartodirdjo, seorang kyai di pesantren, baik di masa lalu maupun sekarang, dianggap sebagai figur sentral yang diyakini mampu merekayasa kehidupan sosial, kultural, dan keagamaan di Indonesia.

\section{Pesantren Sebagai Lembaga Tafaqquh fī al-Dīn}

Pesantren pada umumnya bergerak dalam pendidikan Islam.Peran ini merupakan ciri utama yang mewarnai dalam sejarah pesantren di Indonesia. Kaum muslimin Indonesia mengirim anak-anak mereka ke pesantren untuk belajar agama Islam (tafaqquh $f_{\grave{\imath}}$ al-dīn) dengan harapan mereka tumbuh menjadi muslimahli ilmuilmu agama.

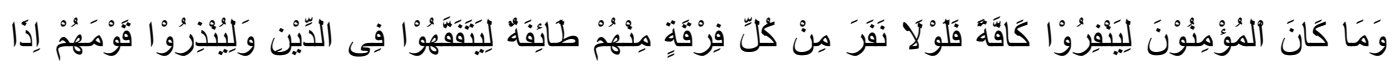

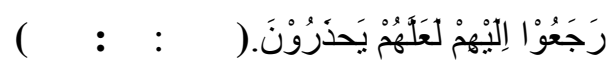

Tidak sepatutnya bagi mukminin itu pergi semuanya (ke medan perang). Mengapa tidak pergi dari tiap-tiap golongan di antara mereka beberapa orang untuk memperdalam pengetahuan mereka tentang agama dan untuk memberi peringatan pada kaumnya apabila mereka telah kembali, supaya mereka itu dapat menjaga dirinya. (QS. Al-Taubah:10: 122) ${ }^{8}$

Kunci dari ayat tersebut di atas bahwa peran santri di pondok pesantren adalah tafaqquh fi al-dinn dan apabila sudah kembali mereka memberikan

\footnotetext{
${ }^{7}$ Ibid, 28-32.

8“al-Qur'an” Terjamahan Departemen Agama RI." (Al-Taubah, 10: 122).
} 
peringatan, pencerahan, dan pemberdayaan bagi kaumnya.Artinya, santri setelah pulang ada di daerahnya mempunyai tugas keagamaan dan sosial kemasyarakatan.

Pesantren memiliki sistem nilai yang unik, sebagaimana ditegaskan Aburrahman Wahid, sistem nilai pesantren mengambil kerangka berpikirnya dari doktrin barakah ${ }^{9}$ yang memancar dari sang kyai kepada santrinya. Keyakinan bahwabimibingan seseorangkyaiatas santrinya merupakan syarat untuk menguasai "pengetahuan agama yang benar", yang itu semua merupakan landasan sistem nilai ini. ${ }^{10}$

Azyumardi Azra mengatakan sebagaimana mengutip perkataan Muhammad Idris Jauhari bahwa kyai atau pimpinan pesantren, tidak saja berfungsi sebagai leader, center figure, dan top-manajer di pesantren masing-masing.Akan tetapi, juga menjadi moral force bagi para santrinya dan seluruh penghuni pesantren, di mana antara santri dan kyai tercipta hubungan batin (bukan sekedar emosional) yang lurus dan kukuh, bahkan sampai ketika mereka sudah pulang ke masyarakat. Suatu kondisi yang seharusnya terdapat dalam lembaga pendidikan apa pun, tetapi sangat jarang ditemukan. ${ }^{11}$

Demikian besar kekuasaan kyai atas diri santrinya sehingga si santri untuk seumur hidupnya akan senantiasa terikat dengan kyainya, minimal sebagai sumber inspirasi dan sebagai penunjang moral dalam kehidupan pribadinya. Dalam urusan

\footnotetext{
${ }^{9}$ Al-Khazin, 'Ala al-Dīn Ali bin Muhmmad bin Ibrahim al-Baghdādī Mashhur Ism al-'Azzam Iman, Tafsir Khazin (Baghdad:Mustofa al-Bab al-Khalabi, 1375 H),218.:

Artinya: "Sesuatu kebaikan Tuhan (Anugerah Allah ) pada sesuatu yang tetap"

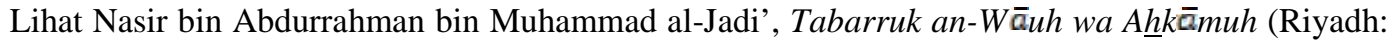
ar-Rasyid, 1995), 25-27. Barakah: mempunyai tiga arti, yaitu: (1) Tetapnya kebaikan yang terus menerus; (2) Tambahnya kebaikan yang banyak; (3) Tetap dan tambah dalam memberikan kebaikan yang banyak dan terus menerus.

Lihat Muhammad bin Alwi al-Maliki al-Hasani, Mafahhim Yajib an Tusahhah, Terjemahan Tarmana Abdul Qasim (Bandung: Remaja Rosdakarya, 2001), 51. Barakah adalah sesuatu yang bisa memberikan ketenangan, kebahagiaan dan tambah kebaikan dari Allah SWT.

Lihat "al-Qur'an" surat al-A'raf: 57 dan 86, Huud: 73, Ali Imran: 137, al-Mu'minun: 12-14, alFurqan: 1,10 dan 61, Ghafir: 64, Az-Zuhruf: 85, ar-Rahman: 78, al-Mulk:1 dan lain-lainnya.

Lihat Nasir bin Abdurrahman bin Muhammad al-Jadi', Tabarruk an-Wāuh wa A $\underline{h} k \bar{a} m u h, 37$, Hadits Rasullah SAW, Hadits Imam Muslim dari Syauban ra.:

من حديث أخرجه الامام مسلم عن ثوبان رضى الله عنه ونصه: كان رسول اله صلم إذا إنصرف من صلاته استغفر ثلاثامرة.

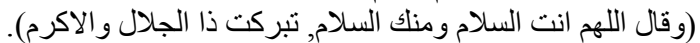

${ }^{10}$ Abdurrahman Wahid, Menggerakkan Tradisi: Esai-Esai Pesantren (Yogyakarta: LKiS, 2001), 241.

${ }^{11}$ Azyumardi Azra, Modernisasi Pendidikan Islam,115.
} 
jodoh, membagi harta pusaka dengan sesama ahli warisnya, bahkan dalam menentukan lapangan pekerjaan pun, seorang santri merasakan kewajiban moral untuk berkonsultasi dan mengikuti petunjuk-petunjuk kyainya.

\section{Tipologi Pesantren}

Secara umum pesantren dapat diklasifikasikan menjadi dua, yakni pesantren salaf(tradisional)dan pesantren khalaf(modern). Sebuah pesantren disebut pesantren salaf jika dalam kegiatannya semata-mata berdasarkan pada pola-pola pengajaran klasik atau lama, yakni berupa pengajian kitab kuning dengan metode pembelajaran tradisional serta belum dikombinasikan denganpola pendidikan modern. Sedangkan pesantren khalaf adalah pesantren yang disamping tetap dilestarikannya unsur-unsur utama pesantren, memasukkan juga ke dalamnya unsur-unsur modern yang ditandai dengan sistem klasikal atau sekolah dan adanya materi ilmu-ilmu umum dalam muatan kurikulumnya. Pada pesantren ini sistem sekolah dan adanya ilmu-ilmu umum digabungkan dengan pola pendidikan pesantren klasik. Dengan demikian, pesantren modern merupakan pendidikan pesantren yang diperbaharuiatau dipermodern pada segi-segi tertentu untuk disesuaikan dengan sistem sekolah. ${ }^{12}$

Menurut Azyumardi Azra pesantren secara general dapat dibedakan menjadi tigamodel, yakni tradisional (salafĩ), modern(khalafī), dan perpaduan antara keduanya. Karakteristik ketiganya digambarkan Jamal Ma'mur Asmanidalam dialektika pesantren dengan tuntunan zaman. Pertama, pesantren salafī kental dengan pengajian yang terbatas pada kitab kuning, intensifikasi musyawarah, berlakunya sistem klasikal, dan kultur serta paradigma berfikirnya didominasi oleh term-term klasik. Kelebihan dari model ini mental kemandirian dan kewirausahaan yang tinggi karena tertantang mengarungi hidup tanpa berbekal ijazah. Kedua, pesantren khalafi digambarkan pada penekanan penguasaan bahasa asing, kurikulumnya mengadopsi kurikulum modern,tidak ada pengajian kitab klasik, penekanan pada rasionalitas, orientasi masa depan persaingan hidup, dan penguasaan teknologi. Kelemahannya, tentu pada penguasaan khazanah

\footnotetext{
${ }^{12}$ Departemen Agama RI, Pola Pembelajaran di Pesantren (Jakarta: Proyek Peningkatan Pondok Pesantren, 2001), 7-8.
} 
klasik.Ketiga, pesantren salaf-semi modern, ada kitab salaf, kurikulum modern, dan ruang kreatifitas santri yang lebih lebar.

Kaitannya dengan pengembangan pesantren Mujamil Qamar mengatakan, ditinjau dari segi keterbukaan terhadap perubahan-perubahan yang terjadi dari luar, pesantren dapat dibagi dua: pesantren tradisional (salafi) dan pesantren modern (khalafī). Pesantren salafī bersifat konservatif, sedangkan pesantren khalafi bersifat adaptif. Adaptasi dilakukan terhadap perubahan dan pengembangan pendidikan yang merupakan akibat dari tuntutan perkembangan sains dan teknologi modern. ${ }^{13}$

\section{Metode Pendidikan Pesantren}

Penyampaian atau penyajian materi di pesantren ada yang bersifat tradisional ada yang bersifat modern. Penyampaian yang bersifat tradisional adalah halaqah, wetonan, dan sorogan.Sedangkan metode modern merupakan metode yang masih diitrodusir berdasarkan pendekatan ilmiah.

\section{Metode-Metode Tradisional}

1) Metode Sorogan (Individual Learning Process)

Merupakan suatu metode yang ditempuh dengan cara guru menyampaikan pelajaran kepada santri secara individual. Sasaran metode ini adalah kelompok santri pada tingkat rendah, yaitu yang baru menguasai pembacaan al-Qur'an atau yang baru belajar al-Qur'an.Disamping itu penerapan metode ini kurang efektif dan efisien karena menghabiskan waktu yang cukup lama.

2) Metode Wetonan

Selainmetodepengajaran dalam bentuk sorogan di pondok pesantren juga terdapat metode wetonan dalam pengajarannya. Metode wetonan adalah kyai membaca suatu kitab dalam waktu tertentu dan santri membawa kitab yang dalam waktu tertentu dan santri membawa kitab yang sama, kemudian santri mendengarkan dan menyimak bacaan kyai tersebut. Metode ini merupakan metode yang utama di lingkungan pesantren. ${ }^{14}$

\footnotetext{
13 Mujamil Qamar, Manajemen Pendidikan Islam, Strategi Baru Pengelolaan Lembaga Pendidikan Islam (Jakarta: Erlangga, 2007),58.

${ }^{14}$ M. Dawam Raharjo (Edit), Pesantren dan Pembaharuan (Jakarta: LP3ES, 1995), 88.
} 
98 - 118 | Tafhim Al-‘Ilmi, September 2019

3) Metode Bandongan (CollectiveLearing Process)

Sildu Galba mengatakan bahwa metode bandongan adalah sistem pengajarankyaimembaca kitab, sementara murid memberi tanda dari struktur kata atau kalimat yang dibaca oleh kyai. ${ }^{15}$ Dalam perakteknya, metode ini lebih menekankan ketaatan kepada kyai.Metode ini lebih menekankan aspek perubahan sikap (moral) setelah santri memahami isi kitab yang dibaca oleh kyai.

4) Halaqah

Halaqahdalamarti bahasanya adalah lingkungan santri. Sedangkan yang dimaksud halaqah di sini adalah sekelompok santri yang belajar di bawahbimbinganseorang guru atauustadh atau kyai yang belajar bersama dalam satu tempat untuk mendiskusikan pemahaman terhadap suatu masalah atau suatu kitab tertentu.

5) Mudhakarah/Mushawarah

Yang dimaksud mudhakarah menurut Ismail dan Abdul Mukti adalah melakukan pertemuan ilmiah secara khusus membahas persoalan agama pada umumnya. Dengan metode ini berfungsi santri terlatih untuk memecahkan suatu permasalahan dengan menggunakan suatu rujukan kitab-kitab yang tersedia. $^{16}$

6) Metode Majelis Ta'lim

Suatu metode menyampaikan ajaran Islam yang bersifat umum dan terbuka, yang dihadiri jamaah yang memilki barbagai back ground pengetahuan, tingkat usia, dan jenis kelamin. Majelis ta'lim adalah lembagapendidikan non-formal Islam yang memilki kurikulum tersendiri, diselenggarakan secara berkala dan teratur dan diikuti oleh jamaah yang relatif banyak dengan tujuan untuk membina dan mengembangkan hubungan yang santun dan serasi antara manusia dengan Allah SWT., antara manusia dengan sesamanya, serta antara manusia dengan lingkungannya, dalam rangka membina masyarakat yang bertaqwa kepada Allah SWT.

\footnotetext{
${ }^{15}$ Sindu Galba, Pesantren Sebagai Wadah Komunikasi (Jakarta: PT.Ineka Cipta, 1995), 57.

${ }^{16}$ Ismail dan Abdul Mukti, Pendidikan Islam, Demokrasi dan Masyarakat Madani (Yogyakarta: Pustaka Pelajar, 2000),177.
} 


\section{Manajemen Pesantren}

Abd.A'la mengatakan, pesantren meski tidak semua, selama ini dikelola seadanya dengan kesan menonjol pada penanganan individual dan bernuansa kharismatik. Orientasi ke depan menjadi kurang jelas dan terbebani persoalanpersoalan praktis keseharian. Visi pesantren yang belum terumuskan secara konkrit menjadi terserap dalam kebijakan-kebijakan pesantren yang bersifat sesaat. $^{17}$

Kondisi tersebut diperburuk lagi dengan aspek metodologis yang selama ini belum mengalami perkembangan cukup berarti.Pola pendidikan dengan pendekatan yang berjalan searah dan monolog sampai derajat tertentu masih banyak didapati dalam pendidikan pesantren.Demikian pula, pengkajian keilmuan itu sendiri masih diletakkan dalam pola pendekatan yang terpisah-pisah.Oleh karena itu, nilai-nilai dan ajaran Islam yang universal, holistik dan saling berkeindahan hanya dapat ditangkap secara parsial dan sepotong-potong.

Demikian pula, model kepemimpinan kharismatik yang selama ini dominan di lingkungan pesantren perlu direkonstruksi secara kreatif berdasarkan nilainilaimodernitasdannilai-nilai Islam itu sendiri. Manajemen kharismatik tersebut tidak harus dieliminasi, tapi disandingkan denganpola rasional dan dibingkai dengan nilai-nilaimoralitas agama. Melalui itu,keterkaitan dua unsur itu akan melahirkan suatu manajemen yang modern tanpa harus kehilangan rohnya yang bersifat moral. $^{18}$

Dalamhubungannya dengan perubahan pesantren,Abdurrahman Wahid mengatakan, banyakhal dapat ditunjuk sebagai belum menetapnya pola kepemimpinan pesantren selama ini, yang paling utama adalah watak kharismatikyang dimilikinya. Pesantren didirikan oleh seseorangyang bercita-cita

\footnotetext{
${ }^{17}$ Abd. A'la, Pembaharuan Pesantren (Yogyakarta: Pustaka Pesantren, 2006), 21.

${ }^{18}$ Ibid, 24. Lebih lanjut lihat juga Azyumardi Azra, Konteks Berteologi di Indonesia....... 166; kepemimpinan kharismatik dapat dikatakan bernuansa moral karena kharisma tersebut, pada umumnya, bermuara pada otoritas keulamaan dalam masalah kedalaman ilmu, ketinggian pribadi, pengelolaan yang hati-hati dalam hubungan-hubungan personal dengan anggota muslim, serta pembinaan reputasi individual. (Hal ini menunjukkan bahwa kharisma ulama berdasar pada keteladanan moralitas yang mereka miliki, pen.).
} 
tinggi dan mampu mewujudkan cita-citanya itu.Proses pendirian pesantren secara sedemikian ini menampilkan seorang pemimpin yang tertimpa oleh pengalaman,memiliki keunggulan kepribadian yang dapat mengalahkan pribadipribadi lain disekitarnya. Kekuatan pribadi seperti itu menimbulkan corak kepemimpinan yang sangat pribadi sifatnya, yang berdasarkan penerimaan masyarakat luar dan warga pesantrennya secara mutlak.Sifat mutlak dan pribadi dari kepemimpinan seperti inilah yang dinamai kharisma. ${ }^{19}$

Bila saja pesantren tradisional sejak semula dikelola secara profesional berdasarkan skill managerial, tentu telah mampu berkembang dengan pesat menjadi pusat kajian keislaman yang progresif dan produktif dalam menghasilkan karya-karya ilmiah yang berbobot. Bahkan dapat mengembangkan kajiannya pada berbagai disiplin ilmu seperti Harvard University di Amerika yang dahulu merupakan "pesantren" umat katolik. Faktor utama keterlambatan ini adalah manajemen.

Olehkarena itu, manajemen yang lemah merupakan satu sisi kelemahan pesantren tradisional. Padahal manajemen yang mapan untuk sebuah institusi semacam pesantren sangat diperlukan agar kelangsungan proses belajar-mengajar dapat berjalan dengan baik, dan pada gilirannya dapat menghasilkan para santri dan alumni yang berkualitas dan responsif terhadap tantangan zaman. Sayangnya, idealisme itu menjadi kandas lantaran pola-pola manajemen yang kontra produktif. $^{20}$

\section{Modernisasi Pendidikan Pesantren}

Dengan tidak meninggalkan ciri khas ke-Islaman, pesantren juga mesti merespon perkembangan zaman dengan cara-cara kreatif, inovatif, dan transformatif. Alhasil, persoalan tantangan zaman modern yang secara realitas seakan menciptakan segala produk amoral seperti dalam gejala global media informasi dapat dijawab secara akurat, tuntas, dan tepat sasaran oleh lembaga pendidikan bernama pesantren.

\footnotetext{
${ }^{19}$ Abdurrahman Wahid, Menggerakkan Tradisi, 180.

${ }^{20}$ Ibid, 59-60.
} 
Responsitas tersebut sebagai bentuk modernisasi pendidikan Islam di pesantren dapat dilakukan dalam beberapa hal di antaranya sebagai berikut:

Pertama,pembaharuan substansi atau isi pendidikan pesantren dengan memasukkan subjek umum dan vokasional.Kedua, pembaharuan metodologi, seperti sistem klasikal dan perjenjangan.Ketiga, pembaharuan kelembagaan, seperti kepemimpinan pesantren dan diversifikasi lembaga pendidikan.Keempat, pembaharuan fungsi, dari fungsi kependidikan untuk juga mencakup fungsi sosial ekonomi. $^{21}$

Dalam khazanahtradisi pesantren, terdapat kaidah hukum yang menarik untuk diaplikasikan oleh pesantren sebagai lembaga pendidikan yang merespontantangan dan "kebaruan” zaman. Kaidah ini berbunyi, "al-muhāfazah

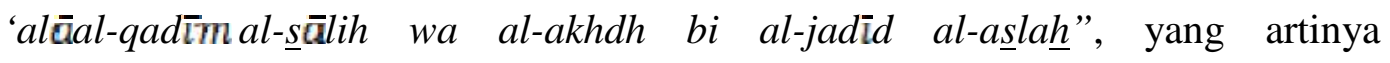
melestarikan nilai Islamlama yang baik dan mengambil nilai baru yang lebih baik. Dengan hal ini mengindikasikanbahwa pesantren patut memelihara nilai-nilai tradisi yang baik sembari mencari nilai-nilai baru yang sesuai dengan konteks zaman agar tercapai akurasi metodologis dalam mencerahkan peradaban bangsa. ${ }^{22}$

Dalam hubungannya dengan modernisasi pesantren, Azyumardi Azra juga mengatakan, kini sementara proses modernisasi pendidikan Islam masih jauh dari pada selesai tantangan baru yang bersifat global telah hadir pula. Tantangan global itu dalam bentuk globalisasi dan "globalisme" menyangkut tidak hanya bidang ekonomi, politik, dan informasi, tetapi dalam bidang pendidikan. Pendidikan Islam, khususnya, pesantren yang sekali lagi bukan hanya merupakan lembaga pendidikan, tetapi juga lembaga dakwah juga tidak luput dari tantangan globalisasi. ${ }^{23}$ Karena itu, tampaknya penting bagi kita memahami apa sebenarnya "globalisasi"; tantangan apa yang dihadirkannya terhadap dunia pendidikan, khususnya, pendidikan Islam-dalam hal ini pesantren; dan bagaimana pesantren seharusnya merespon tantangan globalisasi tersebut.

\footnotetext{
${ }^{21} \mathrm{Ibid}, 215$.

${ }^{22}$ Azyumardi Azra, Modernisasi Pendidikan Islam, 215.

${ }^{23}$ Azyumardi Azra, Pendidikan Islam, Tradisi dan Modernisasi di Tengah Tantangan Milenium III, (Jakarta: Kencana, 2012),133.
} 
Seiring dengan berkembangnya zaman maka peresoalan-persoalan yang harus dihadapi dan dijawab oleh pesantren juga semakin kompleks, dan kita sadari mulai dari sekarang. Persoalan-persoalan yang dihadapi ini tercakup juga dalam pengertian persoalan yang dibawa kehidupan modern atau kemodernan.Artinya, pesantren dihadapkan pada tantangan-tantangan yang ditimbulkan oleh kehidupan modern.Kemampuan pesantren menjawab tantangan tersebut dapat dijadikan tolak ukur seberapa jauh dia mampu menjawab tantangan itu, maka akan memperoleh kualifikasi sebagai lembaga yang modern. Sebaliknya, jika kurang mampu memberikan respon pada kehidupan modern, maka biasanya kualifikasi yang diberikan adalah hal-hal yang menunjukkan sifat ketinggalan zaman, seperti kolot dan konservatif. ${ }^{24}$

Suatu kenyataan sederhana tetapi cukup tajam adalah adanya anggapan bahwa perkataan "modern" mempunyai konotasi "Barat". Meskipun tidak mutlak benar, kita tidak bisa menyalahkan anggapan ini, kerena pada dasarnya masih banyak yang mengakui bahwa nilai-nilai yang dianggap modernitu memang didominasi nilai-nilai dari Barat. Berpijak pada anggapantersebut kita digiring untuk mengakui bahwa peradaban modern yang melanda dunia, termasuk Indonesia, adalah hasil inovasi peradaban Barat. Ada orang yang mengatakan bahwa "modernisasi" sesungguhnya penghalusan dari pengertian "westernisasi". ${ }^{25}$

Dalam kaitannya dengan perubahan pesantren, Abdurrahman Wahid menegaskan bahwa, proses dinamisasi suatu lembaga kemasyarakatan, lebih-lebih yang seperti pesantren, adalah suatu usaha yang rumit dan memakan waktu lama. Tidak ada sebuah konsep pun yang dapat disusun tanpa mengalami perubahanperubahan dalam pelaksanaannya kemudian. Oleh karena itu, dalam kesempatan ini tidak akan ditemui suatu anggapan bahwa kita telah menemukan suatu konsep final yang dapat dipertanggungjawabkan kebenarannya secara ilmiah. Yang akan dikemukakan hanyalah sekedar beberapa gambaran mengenai langkah-langkah apa saja yang dapat diambil untuk memulai proses dinamisasi secara berencana,

\footnotetext{
${ }^{24}$ Nurcholish Madjid, Bilik-Bilik Pesantren, 95.

${ }^{25}$ Ibid, 96.
} 
yang akan dikemukakan pun hanya bersifat langkah dasar permulaan, tanpa ditunjukkan perinciannya.

\section{Strategi Pengelolaan Pesantren}

Masa depan pesantren sangat ditentukan oleh faktor manajerial. ${ }^{26}$ Pesantren kecil akan berkembang secara signifikan manakala dikelola secara profesional. Dengan pengelolaan yang sama, pesantren yang sudah besar akan bertambah besar lagi. Sebaliknya, pesantren yang telah maju akan mengalami kemunduran manakala manajemennya tidak terurus dengan baik. Sementara itu, jika mengabaikan manajemen, pesantren yang kecil akan gulung tikar dalam menghadapi tantangan multidimensi.

Tantangan itu bisa berupa tuntutan-tuntutan keterbukaan (inklusivisme), pengembangan metodologi, kemampuan manajerial, kolektivitas, demokratisasi, kebersamaan, egalitarianisme, dan lain-lain. Semua tantangan itu terakumulasi menjadi satu tantangan besar yang memaksa pesantren untuk mengadakan perubahan manajemen.

Dalam kaitan ini penyelenggaraan manajemen pendidikan pesantren memiliki nilai sama pentingnya dengan upaya menjaga estafet kepemimpinan. Untuk itu, kyai harus menguasai ilmu keislaman, mengetahui tugas-tugas manajerial, sekaligus ilmu keduniaan yang menjadi tuntutan perkembangan zaman. ${ }^{27}$ Dengan pengertian lain, kyai harus visioner dalam menatap masa depan sehingga orientasinya tidak semata-mata pada kecakapan beribadah, tetapi juga kecakapan fungsional dalam menghadapi tantangan-tantangan baru.

Berdasarkan pengamatan terhadap pesantren yang ada, dapat ditegaskan, "Pesantren yang berhasil membutuhkan pemimpin, bukan pengatur. Bahkan, perusahaan yang berhasil juga membutuhkan pemimpin, bukan pengatur". ${ }^{28}$ Ada perbedaan mendasar antara pemimpin dan pengatur. Pengatur lebih berorientasi

\footnotetext{
${ }^{26}$ Musthofa Rahman, Menggugat Manajemen Pesantren, dalam Ismail SM., Nurul Huda dan Abdul Khaliq (Eds), Dinamika Pesantren dan Madrasah (Yogyakarta: Kerja sama Fakultas Tabiyah IAIN Walisongo Semarang dengan Pustaka Belajar, 2002), 107.

${ }^{27}$ Ibid, 116.

${ }^{28}$ Imam Suprayogo, Reformasi Visi Pendidikan Islam (Malang: STAIN Press, 1999), 162.
} 
pada penerapan aturan-aturan legal formal kepada bawahan sehingga sentuhannya bercorak hierarkis-birokratis. Sementara itu, pemimpin lebih berorientasi untuk mengayomi, melindungi, memberi teladan dalam kehidupan sehari-hari, serta memotivasi sehingga sentuhannya lebih bercorak human skill (keahlian menyadarkan orang lain sebagai bawahan).

Kasus pesantren Gontor Ponorogo, misalnya. Mengapa di pesantren ini komunikasi yang dilakukan secara dwibahasa (bahasa Arab dan bahasa Inggris) dalam kehidupan pesantren sehari-hari bisa berhasil sedangkan di pesantren lainnya gagal? Hal ini dikarenakan kyai pengasuh di pesantren gontor benar-benar tampil di depan memberi contoh secara berkelanjutan dan konsisten. Sementara itu, di pesantren yang gagal, kyai hanya memiliki keinginan untuk membentuk bi'ah lughawiyah (lingkungan bahasa) terutama bahasa Arab, tetapi dia sendiri tidak konsisten memberi contoh penerapan komunikasi berbahasa Arab setiap hari. $^{29}$

Selanjutnya pola-pola kepemimpinan kyai di pesantren yang selama ini kurang kondusif menghadapi tantangan-tantanganmodernisasi perlu (bahkan, harus) diubah menjadi pola-pola kepemimpinan yang lebih responsif terhadap tuntutan kemajuan zaman. Pola tersebut haruslah mengarah pada kegiatan yang melibatkan lebih banyak orang lain lagi dalam jajaran kepemimpinan, untuk bersama-sama menjalankan roda organisasi pesantren manuju kondisi yang maju dan mapan, baik dari segi kelembagaan, sistem pendidikan, proses pembelajaran, maupun - tentu saja-kualitas santri. ${ }^{30}$

Dari beberapa kasus, perkembangan ini hendaknya dimulai dari perubahan gaya kepemimpinan pesantren. Yaitu, dari kharismatik menuju rasionalistik, dari otoriter-paternalistik menuju diplomatik-partisipatif, atau darilaissez faire manuju demokratik. $^{31}$ Gaya-gaya kepemimpinan yang diharapkan terwujud tersebut mengarah pada tipe kepemimpinan yang profesional yang memberi perhatian khusus pada partisipasi orang lain dalam menentukan pengembangan pesantren.

\footnotetext{
${ }^{29}$ Ibid, 163.

${ }^{30}$ Ibid, 164.

${ }^{31}$ M. Sulthon Masyhud dan Moh. Khusnuridho, Manajemen Pondok Pesantren (Jakarta: Diva Pustaka, 2003), 15.
} 
Intisari manajemen ada pada kepemimpinan dan intisari kepemimpinan ada pada keputusan. Sebagai seorang pemimpin, kyai harus berani mengambil keputusan, termasuk keputusan yang dilematis, meskipun pada akhirnya keputusan itu baru disadari sebagai keputusan yang salah. Keberanian semacam ini, dalam kehidupan sehari-hari, disebut sebagai power executive. Suatu kekuatan pimpinan yang harus diwujudkan dalam bentuk keputusan-keputusan.

\section{Perguruan Tinggi}

\section{Tugas Pokok Perguruan Tinggi}

Ada tiga tugas utama perguruan tinggi sebenarnya yang dikenal dengan peristilahanTri Dharma Perguruan Tinggi. $^{32}$ Pertama, berkenaan dengan pendidikan pengajaran; Kedua, penelitian; Ketiga, pengabdian kepada masyarakat.

Dharma pertama intinya ialah pentransferan ilmu pengetahuan dari si pendidik (pemberi) kepada peserta didik (penerima). Di sini diperlukan berbagai kelengkapan seperti dosen, mahasiswa, kurikulum, sarana fasilitas pembelajaran, dan manajemen akademik.Dharma kedua ialah erat kaitannya dengan pengembangan ilmu pengetahuan. Lewat penelitian akan ditemukan teori baru ilmu pengetahuan. Dengan ditemukannya teori akan menambah khazanah ilmu pengetahuan di tengah-tengah masyarakat. Ilmu yang dikembangkan lewat dharma pertama dan kedua diterapkan di tengah-tengah masyarakat. Sedangkan dharma ketiga akan diwujudkan di tengah-tengah masyarakat tentang peranan lembaga perguruan tinggi, sehingga perguruan tinggi tidak menjadi menara gading yang jauh terpisah dan tidak tersentuh oleh masyarakat. Konsep dasarnya ialah perguruan tinggi mesti menyatu dengan masyarakat. ${ }^{33}$

Bagi perguruan tinggi agama Islam tugas itu lebih berat lagi, sebab di samping tugas di atas maka perguruan tinggi agama Islam juga memiliki tugas moral dan etis. Tri Dharma tersebut mestilah berada pada bingkai moral. Perguruan tinggi agama Islam mesti berperan sebagai pemikir dan pendistribusi

\footnotetext{
${ }^{32}$ Haidar Putra Daulay dan Nurgaya Pasa, Pendidikan Islam Dalam Mencerdaskan Bangsa (Jakarta: PT. Rineka Cipta, 2012), 67-70.

${ }^{33}$ Ibid, 70-71.
} 
106 - 118 | Tafhim Al-‘Ilmi, September 2019

nilai-nilai moral di tengah-tengah kehidupan masyarakat. Oleh sebab itu mesti ada nilai (value) dan tugas plus bagi lembaga pendidikan tinggi agama. ${ }^{34}$

\section{Landasandan Tujuan Perguruan Tinggi Agama Islam \\ a. Landasan Filosofis}

Landasan filosofi bangsa bertolak dari Pancasila sebagai dasar Negara, yakni sila Ketuhanan Yang Maha Esa.Asas ini mengandung makna bahwa Negara mempunyai tanggung jawab untuk mengembangkan kehidupan beragama bangsa Indonesia.Di sinilah letaknya pandangan berbangsa dan bernegara masyarakat Indonesia, yakni memosisikan agama sebagai bagian yang tidak bisa dilepaskan dari penyelenggaraan Negara.Meletakkan kedudukan di antara dua posisi tidak sekuler dan tidak pula menjadi Negara agama. ${ }^{35}$

\section{b. Landasan Konstitusional UUD 1945, UU RI No. 12 Tahun 2012, dan Kebijakan Politik}

Undang-Undang Dasar 1945, mulai dari Preambul sampai batang tubuh menyinggung masalah yang berkenaan dengan agama. Dalam Preambul dinyatakan bahwa kemerdekaan dicapai atas berkah rahmat Allah SWT.di dalam batang tubuh UUD 1945 dicantumkan masalah yang berkenaan dengan agama. Landasan Undang-Undang RI No. 12 Tahun 2012, pasal 2: Pendidikan Tinggi berdasarkan Pancasila, Undang-Undang Dasar Negara Republik Indonesia Tahun 1945, Negara Kesatuan Republik Indonesia, dan Bhinneka Tunggal Ika. ${ }^{36}$ Landasan kebijakan politik, yang dihasilkan oleh lembaga legislatif MPR, DPR, DPD. ${ }^{37}$

\section{c. Landasan Sosial Religius}

\footnotetext{
${ }^{34}$ Ibid, 71-72.

${ }^{35}$ Ibid, 71-72.

${ }^{36}$ Undang-Undang RI No. 12 Tahun 2012, Undang-Undang Pendidikan Tinggi, (Jakarta: Sinar Grafika, 2012), 6.

${ }^{37}$ Pura Daulay, Pendidikan Islam, 75-76.
} 
Masyarakat Indonesia secara kultural adalah masyarakat religius, karena itu maka untuk menghidupkan serta mendorong agar tumbuh dan berkembangnya semangat keberagaman masyarakat adalah sesuatu yang berlandaskan pada landasan kultural sosial masyarakat Indonesia. ${ }^{38}$

Berbicara mengenai pendidikan, maka perlu melihat ketentuan dan ungkapan yang tertulis di dalam Undang-Undang dan peraturan lain tentang pendidikan. Tentu sajayang sangat penting adalah uraian argumintatif terhadap hal-hal yang seharusnya kita wujudkan (filosofis). Disamping itu juga perlu kita lihat dalam kenyataannya, yaitu apa yang telah menjadi kebijakan dan pelaksanaannya di lapangan. $^{39}$

Undang-UndangPendidikan Tinggi No. 12 tahun 2012 tentang tujuan Perguruan Tinggi sebagai berikut:

1) Berkembangnya potensi Mahasiswa agar menjadi manusia yang beriman dan bertakwa kepada Tuhan Yang Maha Esa dan berakhlak mulia, sehat, berilmu, cakap, kreatif, mandiri, tranpil, kompeten, dan berbudaya untuk kepentingan bangsa;

2) Dihasilkannya lulusan yang menguasai cabang Ilmu Pengetahuan dan/atau Teknologi untuk memenuhi kepentingan nasional dan peningkatan daya saing bangsa;

3) Dihasilkannya Ilmu Pengetahuan dan Teknologi melalui Penelitian yang memperhatikan dan menerapkan nilai Humaniora agar bermamfaat bagi kemajuan bangsa, serta kemajuan peradaban dan kesejahteraan umat manusia; dan

4) Terwujudnya Pengabdian kepada Masyarakat berbasis penalaran dan karya penelitian yang bermanfaat dalam memajukan kesejahteraan umum dan mencerdaskan kehidupan bangsa. ${ }^{40}$

\section{Strategi Pendekatan di Perguruan Tinggi Agama Islam}

\section{a. Integrated Pendekatan Kognitif, Afektif dan Psikomotorik}

\footnotetext{
${ }^{38}$ Ibid, 75-76.

${ }^{39}$ Ibid, 75-76.

${ }^{40}$ Undang-Undang RI No. 12 Tahun 2012, Undang-Undang Pendidikan Tinggi(Jakarta: Sinar Grafika, 2012), 7.
} 
Banyak kesan dari pengamat pendidikanagama bahwa pendidikan agama dilaksanakan di Indonesia sangat dominan pendekatan kognitif mulai dari tingkat dasar sampai pendidikan tinggi. Pendekatan ini, lebih banyak orientasinya kepada pengisian otak yang sifatnya tidak hanya "santapan" otak, bahkan yang lebih dominan adalah "santapan" hati.

Oleh sebab itu maka pendekatan afektif menjadi strategi utama.Apa yang dimaksudkan dengan pendekatan afektif itu? Kamus Umum Bahasa Indonesia menyebutkanbahwa yang dimaksud afektif: $\left.{ }^{41} 1\right)$ berkenaan dengan parasaan;2)keadaan perasaan yang mempengaruhi keadaan penyakit (penyakit jiwa), gaya atau makna yang menunjukkan perasaan.

Kamus Psikhologi menyebutkan: affect, affection: 1) a broad cllas mental processes, including feeling, emotion, moods, and temperament. Historically, affection was distinguished from cognition and volition; 2) (Titchner) pleasantness and unpleasantness. Affectivity:1)emotionality, tendency toward emotional reaction; 2) generalizedemotional reaction ${ }^{42}$.

Berdasarkan ungkapan tersebut dapat diambil kesimpulan bahwa afektif ialah masalah yang berkenaan dengan emosi (kejiwaan)dan yang berkenaan dengan itu, ialah terkait dengan suka, benci, simpati, antipati dan lain sebagainya.Dengan demikian afektif merupakan sikap batin seseorang.

Pendidikan agama yang berorientasi kepada pembentukan afektif ini ialah pembentukan sikap mental peserta didik ke arah menumbuhkan kesadaran agama. Beragama tidakhanya pada kawasan pemikiran, tetapi juga memasuki kawan rasa. Karena itu sentuhan-sentuhan emosi beragama perlu dikembangkan. Di antara metode yang banyak kaitannya dengan sentuhan emosi adalah: ${ }^{43}$

\section{1) Bimbingan Kehidupan Beragama}

Bimbingan kehidupan beragama adalah lembaga konsultasi mahasiswa dalam berbagai problema kehidupan yang dialaminya, terutama berkenaan dengan agama. Diasumsikan (berdasarkan tingkat emosional perkembangan jiwa mahasiswa) banyak di kalangan mahasiswa yang memerlukanbantuan

\footnotetext{
${ }^{41}$ Ibid, 77-78.

${ }^{42}$ Chaplin, Dictionary of Psychologi (New York: Dell Publishing,1973),13-14.

${ }^{43}$ Haidar Putra Daulay dan Nurgaya Pasa, Pendidikan Islam Dalam Mencerdaskan Bangsa, 77-78.
} 
danpertolongandaripihaklainuntukmemberikan jalan keluar dari problema yang dihadapinya.

\section{2) Studi Islam Intensif (SII)}

Kegiatan ini merupakan komplemen dari kegiatan kelas yang terjadwal terstruktur.Bentuknya bisa dalam bentuk diskusi, mudhakarah, pesantren kilat, bedah buku, praktikum ibadah, dan lain sebagainya.

\section{3) Malam Ibadah}

Perlu dijadwalkan adanya latihan spiritual untuk menghayati kebermaknaan beragama di kalangan mahasiswa, seperti mambaca al-Qur'an, zikir, dan lain-lain yang kegiatannya mengarah kepada muhasabah.

\section{4) Dialogis (Two Ways traffics)}

Menghidupkan suasana dialogis berarti menghidupkan pemikiran keagamaan.Pemikiran keagamaandi dalam Islamtelah berkembang sejak abad pertama Hijriyah. Bagi mahasiswa, wacana pemikiran itu perlu ditumbuhkan karena dengan demikian akan memperluas cakrawala pemikirannya. ${ }^{44}$

\section{b. Integrated Pendekatan Sensual, Rasional, Etik dan Transendental}

Pendekatan agama yang dilakukan kepada mahasiswa hurus dilakukan dengan cara rasional, ilmiah dan supra ilmiah. Kepada mahasiswa harus diberikan kesadaran bahwa kebenaran itu memiliki beberapa jenis, sehingga tidak terkesan bahwa kebenaran itu hanya satu saja, yakni kebenaran rasional dan ilmiah.Di samping itu masih ada jenis kebenaran lainnya. Kebenaran transendental, misalnya, ialah sesuatu yang tidak dapat dipisahkan dalam ajaran Islam. Kebenaran inidapat digolongkan kepada kebenaran supra ilmiah. Seseorang harusdapat membedakan dan mendudukkan masing-masing pada posisinya.Dan ketika berbicara alam nyata dipergunakan pendekatan sensual, rasional dan ilmiah.

\footnotetext{
${ }^{44}$ Ibid, $78-80$.
} 
110 - 118 | Tafhim Al-'Ilmi, September 2019

Pendekatan-pendekatan tersebut erat kaitannya dengan pendekatan yang dilakukan oleh al-Qur' an berbicara tentang hal-hal yang bersifat indrawi, rasional dan supra rasional.

\section{c. Pendekatan Integrited Keilmuan}

Ilmu dalam pandangan Islam terbagi pada dua. Pertama, perennial knowledgeyaituilmu yang bersumber dari wahyu. Kedua, ilmuyang tergolong acquired knowledge. Kedua ilmu itu masing-masing berbeda ontologisnya dan epistimologinya serta axiologisnya. Agar nilai-nilai Islammunculdalamilmu pengetahuan, maka diperlukan pendekatan integrated diantara ilmu yang disebutkan itu. ${ }^{45}$

\section{Peta Pendidikan Tinggi Islam di Indonesia}

Sebelum kita bahas peta pendidikan tinggi Islam, perlu disadari apa batasan pendidikan tinggi Islam. Pendidikan Tinggi Islam ialah sekolah tinggi atau institut yang konsentrasi pengembangan keilmuannya ialah ilmu-ilmu agama Islam.Universitas yang dalam statutanya menyebutkan Universitas Islam serta menyelenggarakan perkuliahan ilmu-ilmu agama Islam.Untuk menganalisis peta pendidikan tinggi Islam di Indonesia perlu dikedepankan analisis SWOT (Strengths, Weakness, Opportunities, Threats).Oleh beragamnya perguruan tinggi Islam, maka analisis SWOT yang dikemukakan yang bersifat umum, dimiliki oleh hampir seluruh perguruan tinggi Islam. ${ }^{46}$

\section{a. Strengths}

Dukungan Landasan filosofis Pancasila, Undang-Undang Dasar 1945, dan keputusan-keputusan politik yang memberi peluang untuk eksisnya Lembaga Pendidikan Tinggi Islam.Dukungan umat Islam Indonesia yang menginginkan agar adanya Lembaga Pendidikan Islam di Indonesia. Banyaknya Lembaga

\footnotetext{
${ }^{45} \mathrm{Ibid}, 81$

${ }^{46} \mathrm{Ibid}, 81$.
} 
Pendidikan Islam tingkat dasar dan menengah yang menjadi raw input bagi Pendidikan Tinggi Islam, seperti: pesantren, sekolah, dan madrasah.

\section{b. Weakness}

Pendanaan yang terbatas, sehingga berdampak kepada pengembangan yang terbatas pula.Sumber Daya Manusia pengelolanya baik tenaga administrasi maupun dosen masih terbatas, baik dari segi kuantitas maupun kualitas.Terbatasnya sarana dan fasilitas. Terbatasnya aset-aset yang dapat dikembangkan guna dijadikan sumber dana.

\section{c. Opportunities}

Harapan masyarakat, terutama umat Islam, sangat besar terhadap Pendidikan Tinggi Islam. Semakin sadarnya masyarakat Indonesia, terutama umat Islam tentang kedudukan perguruan tinggi dalam era globalisasi guna membentuk manusia unggul, semakin banyak Lembaga Pendidikan Tinggi Islam yang berkualitas sehingga digandrungi masyarakat.

\section{d. Threats}

Masih banyak perguruan tinggi Islam yang masih dalam proses pembinaan sehingga dikhawatirkan kalah bersaing di era persaingan sekarang. Semakin sulitnya mendapat lowongan kerja bagi Pendidikan Tinggi Islam terutama alumni ilmu-ilmu KeIslaman. ${ }^{47}$

\section{Peranan Pendidikan Tinggi Agama Islam Dalam Pengembangan Pendidikan Islam}

Bertolak dari tugas pokok pendidikan tinggi maka dapat dilahirkan gagasan tentang apa saja peranan lembaga pendidikan tinggi dalam mengembangkan pendidikan agama Dharma pertama; pendidikan dan pengajaran. Lewat pendidikanpengajaran dipersiapkan materi-materi pelajaran apa yang akan diberikan kepada peserta didik agar dia tumbuh kelak menjadi seorang guru

\footnotetext{
${ }^{47}$ Ibid,89-90.
} 
agama yang bermutu, yang berkompeten dalam bidang tugasnya. Secara garis besar harus diberikan kepadanya tiga rumpun keilmuan. Pertama, rumpun ilmu yang akan diajarkannya, dalam hal mata pelajaran keagamaan (keimanan, ibadah, akhlak dan lain sebagainya). Kedua, rumpun ilmu keguruan (ilmu pendidikan, strategi belajar mengajar, psikologi dan lain-lain).Ketiga, rumpun ilmu perluasan wawasan (ilmu kealaman, sosial). ${ }^{48}$

Lewat Dharma kedua, dapat dilakukan penelitian-penelitan yang bersifat applied research. Bidang-bidang yang diteliti menyentuh langsung tentang hal yang berkenaan dengan problematika pendidikan agama.Hasil penelitian itu dapat dijadikan masukan dan solusi.

Selanjutnya, melalui Dharma pengabdian kepada masyarakat, dosen dan mahasiswa terjun ke masyarakat memasuki majelis-majelis ta'lim, memberikan serangkaian ceramah yang sistematis, terencana, punya kurikulum dan silabus berisikan tentang pendidikan Islam. Ceramah itu dapat bermuatan pendidikan Islam sebagai mata pelajaran, dan dapat juga bermuatan tentang metode mengajarkan agama bagi anak-anak dan remaja di rumah tangga, sehingga hasilnya berguna bagi masyarakat untuk mendidik anak-anak mereka. ${ }^{49}$

\section{Arah Pendidikan Agama Islam di Perguruan Tinggi}

Undang-Undang Republik Indonesia Nomor 12 Tahun 2012 Tentang Pendidikan Tinggi bahwa mengamanatkan kepada Pemerintah untuk mengusahakan dan menyelenggarakan satu sistem pendidikan nasional yang meningkatkan keimanan, ketakwaan kepada Tuhan Yang Maha Esa, dan akhlak mulia dalam rangka mencerdaskan kehidupan bangsa serta memajukan ilmu pengetahuan dan teknologi dengan menjunjung tinggi nilai-nilai agama dan persatuan bangsa untuk kemajuan peradaban serta kesejahteraan umat manusia. ${ }^{50}$

\footnotetext{
${ }^{48}$ Ibid, 89-90.

${ }^{49}$ Putra Daulay, Pendidikan Islam, 71-72.

${ }^{50}$ Undang-Undang RI No. 12 Tahun 2012, Tentang Pendidika Tinggi 2012(Jakarta: Sinar Grafika, 2012), 01 .
} 
Lembaga pendidikan tinggi adalah lembaga ilmiah, maka seharusnya pula pendidikan agama yang diberikan disesuaikan dengan tingkat berpikir mahasiswa tersebut. Dalam hal ini diperlukan pembahasan-pembahasan di samping prinsipdan dasar-dasar agama Islamperlu diberikan pembahasan dan sentuhan sesuai dengan bidang disiplin ilmu yang ditekuninya.

\section{Tantangan Perguruan Tinggi AgamaIslam di Era Globalisasi dan Informasi}

Kehadiran lembaga pendidikan tinggi merupakan sahutan terhadap kebutuhan masyarakat untuk merealisasikan kehidupan beragama di tanah air ini. Masyarakat Indonesia yang religius meletakkan sila Ketuhanan Yang Maha Esa sebagai sila pertama, adalah menunjukkan betapa urgennya kehidupan agama di Indonesia.

Perjalanan lembaga ini yang sudah lebih dari setengah abad telah memberikan sumbangan yang amat bermakna bagi pembangunan bangsa dan negara. Produk-produknya telah tersebar luas di tengah-tengah masyarakat yang tentunya merupakan aset bangsa yang amat berharga.

Dinamika perkembangan masyarakat bergulir terus tidak bisa dikekang, kemajuan ilmu pengetahuan dan teknologi membawa perubahan dahsyat bagi kehidupan manusia, baik cara pandang maupun gaya hidupnya. Perguruan tinggi adalah lembaga yang terkait erat dengan masyarakat, sebab input perguruan tinggi berasal dari masyarakat dan out put perguruan tinggi diserap oleh masyarakat. Karena itulah perguruan tinggi mesti peka terhadap perkembangan masyarakat. ${ }^{51}$

\section{a. Tantangan Globalisasi}

Dunia tanpa batas adalah kenyataan hidup kita saat sekarang, sekat-sekat batas antara negara telah menipis.Di dunia yang seperti ini maka harus keluar masuk manusia, jasa, teknologi, barang, ke suatu negara adalah sesuatu yang lumrah.Selain itu saling pengaruh budayapun tidak bisa dihindari. Pengaruh ini semua tidak bisa dihindari dan akan terjadi persaingan global. Pola alamkompetitif maka kualitas menjadi handalan. Karena kualitas menjadi handalan maka peranan perguruan tinggi semakin dominan untuk membentuk

\footnotetext{
${ }^{51}$ Ibid, 84-85.
} 
manusia berkualitas tersebut. Jadi dengan demikian perguruan tinggi masa depan adalah peguruan tinggi bermutu. ${ }^{52}$

\section{b. Tantangan Perkembangan Ilmu Teknologi}

Sejak keberadaan manusia di bumi secara evolusi dan gradual telah terjadi perkembangan ilmu pengetahuan dan teknologi. ${ }^{53}$ Banyak penemuan baru sebagai hasil dari upaya manusia mengembangkan ilmu tersebut. Dipandang dari sudut konsep keilmuan dalam Islam, ilmu itu terbagi pada dua macam, sesuai dengan hasil Konfrensi Pendidikan Islam se-Dunia, yaitu ilmu yang tergolong perennial knowledge dan ilmu yang tergolong acquired knowledge. Ilmu perennial knowledge ialah yang bersumber dari wahyu, sedangkan ilmu acquired knowledgeialah ilmu yang bersumber dari perolehan manusia. Dalam konsep Islam, kedua jenis keilmuan itu menyatu dalam satu kesatuan.

Bertolak dari konsep tersebut, maka idealnya suatu Lembaga Pendidikan TinggiIslamadalah mengembangkan kedua ilmu tersebut secara simultan, tanpa memisahkannya apalagi mempertahankannya. Untuk mengembangkan kedua ilmu tersebut secara seimbang, maka perlu dirancang pengembangan kedua ilmu tersebut.

Salah satu dampak negatif dari kemajuan-kemajuan ilmu dan teknologi serta globalisasi, ialah munculnya semangat hedonism. Hedonism ini ialah pandangan bahwa tujuan kehidupan adalah usaha mencapai segala kenikmatan fisik setinggi mungkin, sesering mungkin dan dengan cara apa pun tanpa memperhatikan konsekwensi yang mungkin dialami ${ }^{54}$

\section{Manajemen Perguruan Tinggi Islam}

Upaya tokoh-tokoh Islam untuk memberdayakan umat Islam di Indonesia dalam jalur pendidikan juga diwujudkan dengan mendirikan perguruan tinggi Islam sebagai sebuah lembaga lanjutan. Upaya ini disempurnakan secara berkesinambungan mulai dari awal hingga sekarang dengan berbagai terobosan yang bersifat politis, kultural, sosial, maupun birokratif.

\footnotetext{
${ }^{52}$ Ibid, 98.

${ }^{53}$ Ibid, 98.

${ }^{54}$ Team Penulis Rosda, Kamus Filsafat (Bandung: Remaja Rosdakarya, 1995), 135.
} 
Secara kuantitatif, upaya tersebut dapat dinilai berhasil karena belakangan ini telah bermunculan berbagai perguruan tinggi yang berlabel Islam. Perguruan tinggi mulai dari yang beralokasi di ibu kota (Jakarta) hingga di wilayah kecamatan yang tersebar di berbagai penjuru pulau Jawa. Bahkan, ada pula dalam satu kecamatan, terdapat tiga perguruan tinggi Islam seperti yang terjadi di kecamatan Pacitan, Lamongan. Akan tetapi, secara kualitatif perguruan tersebut masih jauh dari harapan yang ideal sehingga hal ini membutuhkan penanganan yang lebih profesional dan serius untuk meningkatkan mutunya. ${ }^{55}$

Menurut Nur Syam, perubahan terjadi karena ada beberapa hal, yaitu inovasi yang datang dari dalam maupun dari luar, motivasi kuat untuk berubah, dan penerapan skenario perubahan (penerapan akselaratif). ${ }^{56}$ Inovasi dari luar utamanya memberikan rangsangan untuk berubah, motivasi membangun kesadaran untuk berubah, sedangkan skenario mengadakan perubahan yang dikondisikan sesuai dengan program yang direncanakan.

\section{Solusi Penataan Perguruan Tinggi Agama Islam}

Problem-problem seriusyang dihadapi oleh PTAI harus segera diatasi. Pihak yangpaling bertanggung jawab adalah para pemimpin perguruan tinggi agama Islam tersebut karena mereka merupkan pengendali, walaupun problem-problem itu bisa saja terjadi karena ulah orang lain. Kemudian, seluruhcivitas akademika harus merespons dengan kompak untuk mendukung pimpinan dalam mengadakan pembenahan.

Perguruan tinggi Islam harus segera melakukan pembenahan dalam berbagai aspek, baik yang berhubungan dengan perangkat keras maupun perangkat lunak dalam rangka menghadapi tantangan masa depan.Kata kuncinya hanya satu, yaitu angrem (menunggui) kampus yang berlaku bagi pimpinan dan civitas akademiknya. Jangan harap anak ayamakan menetas dengan baik jika induk ayam tidak mau mengerami dengan sungguh-sungguh. Sebab, membangun perguruan tinggi merupakan upaya membangun manusia profesional-intelektual supaya

\footnotetext{
${ }^{55}$ Mujamil Qomar, Manajemen Pendidikan Islam, 100.

${ }^{56}$ Nur Syam, Kepemimpinan Dalam Pengembangan Pondok Pesantren, dalam A. Halim et.al (eds), Manajemen Pesantren (Yogyakarta: Gema Insani, 2005), 37.
} 
116 - 118 | Tafhim Al-'Ilmi, September 2019

mereka mampu bergaul ditengah-tengah komunitas global secara dinamis, kreatif, dan inovatif. ${ }^{57}$

\section{Penutup}

Perguruan tinggi di pesantren dituntut mampu merumuskan konsep pengembangan ajaran Islam sebagai tatanan sosial, bukan hanya sebagai lembaga legalistik hitam putih. Dalam hal ini kemampuan antisipatif dan keterbukan akanmempermudah perguruan tinggi menjalankan perannya. Keterbukaan akan menumbuhkan sikap lentur dan akomodatif.

Perguruan tinggi di pesantren menentang eksistensinya sendiri bila di satu sisi menerima tugas sebagai pelopor perubahansosialuntuk menatap masa depan, sedangkan di lain sisi ia tertutup terhadap pembaruan dan malah mencurigai masa depan. Dan demikian benar juga, perguruan tinggi di pesantren mengingkari misinya, apabila ia menerima dan mengemban tugas mendidik generasi muda sebagai penerus Islam, dengan jalan memprogram mereka agar mencerna dan hanya mengawetkan nilai-nilai kehidupan yang sudah kehilangan relevansi aktualnya. Sementara di luar lembaga itu, terjadi berbagai perubahan yang sangat serius dan dahsyat dalam hampir semua bidang kehidupan.

\section{Daftar Pustaka}

Abdullah, Amin.Islamic Studies di Perguruan Tinggi, Pendekatan IntegratifInterkonektif. Yogyakarta: Pustaka Pelajar, 2012.

Antologi Kajian Islam. Surabaya: Pascasarjana IAIN Sunan Ampel Press, 2011.

Ary, Donald.Et. Al. Introduction to Research in Education. New York: Holt. Rinehart \& Winston, Inc, 1985.

Atiqullah.Perilaku Kepemimpinan Kolektif Pesantren. Jember: Buku Pena Salsabila, 2011.

\footnotetext{
${ }^{57}$ Ibid, 106.
} 

Pelajar.

Azizy, A. Qodri. Pengembangan Ilmu-Ilmu KeIslaman. Semarang: Aneka Ilmu, 2004.

Azra, Azyumardi. Modernisasi Pendidikan Islam,AlaAzyumardi Azra. Yogyakarta: Ar-Ruzz Media, 2001

Baharuddin dan Umiarso. Kepemimpinan Pendidikan Islam: Antara Teori dan Praktik. Yogyakarta: Ar-Ruzz Media, 2012.

Bakker, Anton. Metodologi Penelitian Filsafat. Yogyakarta: Kanisius,1990.

Basrowi.Memahami Penelitian Kualitatif. Jakarta: PT. Rineka Cipta, 2008.

Bruinessen, Martin Van. Kitab Kuning, Pesantren dan Tarekat. Yogyakarta: Gading Publishing, 2012.

Chaplin, J.P. Dictionary of Psychologi. New York: Dell Publishing,1973.

Dewan Riset Nasional.Panduan Pembentukan dan Penyelenggaraan Dewan Riset Daerah (DRD). Jakarta: Kantor Menristek,2001.

Dhafir, Zamakhsyari. Tradisi Pesantren: Studi Tentang Pandangan Hidup Kyai. Jakarta: LP3ES, 1982.

Dulay, Heidar Putra. Language.Yogyakarta: Pustaka Pelajar, 1982.

.Pendidikan Islam Dalam Mencerdaskan Bangsa. Jakarta: PT. Rineka Cipta, 2012.

.Pendidikan Islam: Dalam Sistem Pendidikan Islam di Indonesia. Jakarta: Kencana, 2004.

Garna, Judistira K. Teori-Teori Perubahan Sosial. Bandung: Program Pascasarjana Universitas Pajajaran, 1992.

Hamalik, Oemar. Metodologi Pengajaran Ilmu Pendidikan. Bandung: Mandar Maju, 1989.

Harson, Mark.Educational Reform and The Transition From Authoritarian to Democratic Govements: The Cases of Argentina, Colombia, Venezuela, and Spain, Dalam Internasioal Jurnal of Education Development. Vol 32, No. 1.1997.

Komariah, Aan dan Cepi Triana.Visionary Leardership: Menuju Sekolah Efektif. Jakarta: PT. Bumi Aksara, 2006. 
118 - 118 | Tafhim Al-`Ilmi, September 2019

Maimun.Modernisasi Pengelolaan Pesantren: Studi Kasus di Pondok Pesantren Haromain Putri Narmada, Dalam Jurnal Penelitian KeIslaman.Vol. 3 No. 2 Juni 2007.

Majid, Nurchalish. Bilik-Bilik Pesantren. Jakarta: Dian Rakyat, 2010.

.Tradisi Islam, Peran dan Fungsinya Dalam Pembangunan di Indonesia. Jakarta: Paramadina, 2008.

.Paradigma Pendidikan Islam,Upaya Mengefektifkan Pendidikan Agama Islam di Sekolah. Bandung: Remaja Rosda Karya, Cetakan III, 2004.

Purwanto, Ngalim.Administrasi dan Supervisi Pendidikan. Bandung: PT. Rosdakarya, 2007.

Qomar, Mujamil. Manajemen Pendidikan Islam. Jakarta: Erlangga, 2007.

Rahim, Husni. Arah Baru Pendidikan Islam di Indonesia. Jakarta: Logos, 2001.

Rahmat, Jalaluddin. Mempersoalkan Asal Usul Pemimpin Islam, Dalam Maksum (ed)., Mencari Pemimpin Umat: Polemik Tentang Kepemimpinan Islam di Tengah Pluralitas Masyarakat. Yogyakarta: LkiS, 1999.

Rasmianto.Perubahan Pendidikan Tinggi Islam (Studi Tentang Pembaharuan Konsep Institusi dan Budaya Pendidikan di Universitas Islam Negeri (UIN) Syarif Hidayatullah dan Universitas Islam Negeri (UIN) Malang).

Turhan Yani, Muhammad. Dinamika Pendidikan Islam di Perguruan Tinggi Umum.Diseertasi PPs IAIN sunan Ampel Surabaya, 2009. 